\title{
Accounting in Turkey
}

\author{
Can Simga-Mugan \\ Bilkent University
}

\begin{abstract}
Turkey is a developing country in the Middle East, and is attracting an increasing number of foreign investments and joint ventures. However, the Turkish accounting system is not one of the topics that is studied in detail, the language barrier perhaps being the main reason. As the amount of foreign investment and the number of joint ventures increase and the Turkish stock market develops, a new responsibility will fall on accountants to disclose and discuss the current accounting system in Turkey. This paper attempts to fill this gap by describing the current accounting system and state of the profession in Turkey.
\end{abstract}

\section{INTRODUCTION}

As companies enter the global market to increase their profitability, and to sustain their growth, international accounting has become a major area of interest. Internationalization of business activities has placed a new burden on accountants to interpret and analyse financial statements prepared in different countries.

A recent report on US manufacturers in the global marketplace by the Conference Board states that companies which are active in Eastern Europe, Central Europe, Latin America and the Middle East achieve higher profits than the companies involved in Western Europe and North America (Deloitte and Touche Review, 18 April 1994). Although Turkey is a developing country in the Middle East, the Turkish accounting system has not been studied in detail, the language barrier perhaps being the main reason for this. In the last two decades a few studies have addressed different topics of the Turkish accounting environment, such as the role of accounting in the development of capital markets and economic develop-

\footnotetext{
Address for correspondence

Department of Management, Faculty of Business Administration, Bilkent University, 06533, Bilkent, Ankara, Turkey.

(C) 1995 European Accounting Association

0963-8180
} 
ment, and the efficiency of the Turkish accounting system over that period (Goktan, 1968; Tumer, 1972; Var, 1976; Ogan, 1978; Bursal, 1984). A more recent paper discussed the perceptions of small business accountants (Agarwal and Joshi, 1991). As the amount of foreign investment and the number of joint ventures increase and the Turkish stock market develops, a new responsibility will fall on accountants to explain and discuss the current accounting system in Turkey. This paper attempts to fill the gap by describing the current accounting system and the state of the profession in Turkey.

Before proceeding with a discussion of the current practices, a brief history of accounting in Turkey will be given. The paper will present current accounting and auditing practices in Turkey, emphasizing variations from the international accounting principles set by the International Accounting Standards Board.

\section{A BRIEF HISTORY OF ACCOUNTING IN TURKEY}

The development of accounting practice in Turkey has been heavily influenced by the practices of a number of Western countries as a result of economic and political ties over the past two centuries. The first Commercial Code of 1850 is a translation of the French Commercial Code, and reflects the French influence of the era. This Law was the first accounting regulation in Turkey (Bilginoglu, 1988).

The end of the nineteenth and the beginning of the twentieth century marked the alliance of Turkey with Germany. By the end of 1915 most of the 219 private industrial businesses in the country were controlled by foreign investors. Foreign capital controlled seven railway concessions, six mines, twenty-three banks, eleven municipal concessions, twelve industrial companies and thirty-five commercial companies in 1924. These companies were mostly controlled and operated by French and German entrepreneurs (Walstedt, 1980).

Turkey's alliance with Germany during the First World War eventually led to the dismantling of the Ottoman Empire. As rightly pointed out by Walsted (1980), the Turkish War of Liberation, 1919-1923, was fought against imperialist capitalism rather than the capitalist system itself.

After the First World War the allies wanted to restore the capitulations and also to establish an Allied Control Commission to supervise the financial and fiscal affairs of Turkey. The attitude of the victorious allies after the First World War and during the peace talks after the War of Liberation aroused strong antagonism. Historical and political developments and the fact that most foreign manufacturing businesses had been operated by the Germans led to strong German influence on the economic development of the emerging state of Turkey.

Following the establishment of the Turkish Republic in 1923, a second 
Commercial Code was enacted by Law No. 826 in 1926 . This code is based on the German commerce and company laws. In the 1923-1927 period Turkey used private enterprise as the engine of industrialization. An economic conference was called in Izmir in 1924, where various resolutions were passed with the aim of supporting national private industrial development. Supports included the provision of credit incentives to industry, the establishment of a main commercial bank, free factory site donations by the state and freight reductions on state railroads. The results of the liberal measures between 1923 and 1929, showed to some extent that a weak private sector cannot be the agent of development. The world recession, payment of the huge Ottoman foreign debt in 1928 and a reduction in export revenues as a result of a world slump in agricultural prices were also contributory factors to the apparent inefficiency of the private sector as a development agent (Turkiyede Toplumsal, 1989).

As a result, the country turned toward etatisme. Bernard Lewis who is an authority on Turkey, defines étatisme as

the intervention of the state as pioneer and director of industrial activity, in the interest of national development and security, in a country in which private sector is either suspect or ineffective (Walstedt, 1980: 60).

The planned development era started in 1933. In order to establish the first Five-Year Industrial Plan, foreign expertise was used to determine where different industries should be located. For example, the major steel factory site selection project was prepared concurrently by Soviet, German, American, and British experts, and the decision was reached after all the reports had been evaluated (Turkije'de Ekonomik, 1989).

The first state economic enterprise (SEE), Sumerbank, was founded in 1933. It was originally entrusted with the operation of the principal mines recently acquired through nationalization. It is therefore not surprising to note that its accounting system was organized by the Germans. One of the objectives of the SEEs was to assist in development of the private sector (Walstedt, 1980: 72-3). German influence was also carried over to the private sector.

Furthermore, in the late 1930s, Turkey welcomed German academicians of various fields in the Turkish universities. Consequently, the financial and cost accounting practices of the SEEs, and the teachings of visiting German professors established the rules for accounting practice in private companies (Bilginoglu, 1988).

Although the first plan was successful to a great extent, the Second World War prevented the implementation of the second Five-Year Plan. The period of 1941-1950 was one of economic conservatism in which the Turkish economy was stagnant, and entered a recession period which was principally the result of the war. The country engaged in very limited foreign trade, and suffered high price increases, additional taxes, changes in 
industrial products and reductions in the labour force to meet military demands. As a result, the spirit of private entrepreneurship waned.

In the first three decades of the Republic, between 1920 and 1950, the Turkish economy was a conservative one in which the state initiated the economic activities. After World War II, developments in the world economy such as the Bretton Woods economic conference affected Turkish economy and Turkish politics. The establishment of a multiparty era in 1946 led to a limited liberation movement during this decade. In 1950 the Turkish Industrial Development Bank was founded with support from the World Bank to foster and finance private industrial investment. In the early 1950 s the country enjoyed an economic growth it had never seen before as a consequence of agricultural production. This economic boom ended in the mid1950 s and was followed by a period of economic crisis. A major outcome of the crisis was the need for foreign loans. These developments eventually led to the IMF-imposed stabilization programme in 1958 (Ceyhun, 1992).

The decade of 1950-1960 marks the first attempts towards a more liberal economy in which international trade gained momentum (Kilicbay, 1991). These developments led to the enactment of the current Commercial Code of 1956 which came into effect in 1 January 1957. In 1959 Turkey applied for membership of the European Economic Community. However, Turkey is not even now a full member. Therefore, although the Fourth, Seventh and Eighth Directives have been translated and discussed in various circles, no action has been taken to incorporate them into regulations.

During the decade of 1950-1960, incentives were provided for the private sector and for foreign investment. From the second half of the decade on, American expertise was utilized and the economic system has been heavily influenced by the American system.

Successful individuals in various fields have been trained and have taken graduate degrees in foreign countries, especially the USA, from the late 1950son. After the return of these individuals, the accounting system was heavily influenced by the American system from the beginning of the 1960 s. The development of a uniform chart of accounts for SEEs in 1974 reinforced the effect. American influence was also seen in the curriculum of the business schools, especially in the field of business administration and accounting.

After the military coup in 1960 the economy once again returned to a mixed system in which the state initiated activities along with the private sector; 1963 was the start of the first Five-Year Development Plan period. This plan was intended to provide a guide for the private sector. Several incentives were provided to the private sector, which included:

1 accelerated depreciation;

2 investment tax credit; and

3 tax exemption from customs duty and taxes. 
The decade of 1970-1980 was an era of political turmoil, in which the government was forced to resign in March 1971 by the military. In the following years coalition governments were unable to stabilize the social and political turmoil in the county. The political instability and the oil crises in 1973 and 1974 had adverse effects on the Turkish economy. From 1977 on, Turkey faced great difficulties in meeting foreign debt payments and encountered import bottlenecks. The wholesale price index reached to levels of 63.9 per cent per annum in 1979 and 107.2 per cent per annum in 1980 .

In January 1980 a series of economic decisions imposed by the IMF were taken to reduce the inflation rate, to increase production and to support importing activities. In September 1980 Turkey suffered another military coup. The period between 1980 and 1983 can be classified as a 'transition to democracy'. After the 1983 election, an expanded version of the January 1980 economic decisions were put into effect.

In the reconstruction period starting in the 1980s, Law No. 2499 was put into effect in 1981 to prepare the grounds for establishing the capital markets. The Law of Istanbul Stock Exchange came out in 1984, but full operations started only in 1986. The founding of the capital markets and the Istanbul Stock Exchange, and the increase in foreign investment ${ }^{1}$ promoted the development of accounting and auditing standards. Increase in joint ventures and foreign trade led to the 'Big Eight' establishing offices in Turkey. As a result of these developments, large private enterprises started to apply the international accounting standards in their accounting system.

The first set of financial accounting standards were developed in January 1989 by the Capital Markets Board (CMB) to come into effect for fiscal years starting on or after 1 January 1989 (Sermaye Piyasasi, 1989). These financial accounting standards, which control the preparation and presentation of financial statements of publicly traded companies, insurance companies, banks and brokerage firms, are comparable with international accounting standards.

As will be apparent from the above discussion, the legal environment surrounding accounting practices in Turkey has passed through several transformations. However, accounting principles did not show a similar development and accounting was, and to some extent still is, treated as identical with book-keeping. Moreover, although there have been several attempts to form an accounting body since 1940s, until recently there have been none to pursue the establishment of standards. The main reason for this delay is the lack of pressure on Turkish companies to provide publicly available and comparable financial statements, because most businesses have historically been family owned. The accountants in such companies are responsible for book-keeping for tax purposes (i.e. following the procedural tax code), cash management, budgeting, preparation of tax returns and financial statements required by the tax codes and very limited 
internal auditing. In some larger firms, there are different departments for cost and financial accounting.

Until the establishment of the CMB and the Istanbul Stock Exchange, the main influence on the financial accounting system was the legal requirements. Consequently, accounting practice in Turkey is heavily regulated by tax rules, and could therefore be classified as tax accounting.

In 1992 the Ministry of Finance organized a committee to establish accounting principles and a uniform chart of accounts. The Ministry published the committee's report in a communiqué on 26 December 1992, establishing the principles and the uniform chart of accounts to be in effect from 1 January 1994 (Maliye ve Gumruk, 1992). All companies except banks, brokerage firms and insurance companies are required to observe the guidelines stated in the communiqué. This regulation superseded the standards set by CMB earlier for preparation and presentation of financial statements for publicly traded companies, although the two sets of principles are basically the same. Companies should follow the requirements of the Commercial Code and the Procedural Tax Law in determining their taxable incomes. The Ministry of Finance issued these standards for two main reasons: (1) enforcement of the rules applies to all companies, not just to the companies that are controlled by the CMB; and (2) traditionally it is the Ministry that has set accounting rules.

In February 1994 an Accounting and Auditing Committee was formed with the mission to develop accounting and auditing standards. This committee is composed of academicians, government auditors, representatives of the Treasury, the prime minister's Audit Board, the CMB, the Ministry of Finance and Turkish independent accountant financial advisers and sworn-in financial advisers.

The official objective of financial accounting in Turkey is to comply with the requirements of the Ministry of Finance regulation of 1992 which states that the financial statements must be prepared to show a true and fair view of a company's financial situation.

As a developing country with an emerging stock market and an increasing number of foreign investments, the unofficial objective of financial accounting is to develop accounting standards which will lead to financial statements that are internationally comparable and understandable.

\section{FINANCIAL ACCOUNTING}

Financial accounting is regulated presently by the Ministry of Finance's regulation of 1992, CMB rules, the Commercial Code and the Procedural Tax Law and Central Bank regulations.

The Commercial Code and the Procedural Tax Law establish the disclosures required in the financial statements of all profit-making companies. These companies must also meet requirements in the Ministry of Finance's 
communiqué of 1992 . The finance companies, on the other hand, are regulated by the CMB standards and tax codes. Banks are controlled and regulated by the Central Bank regulations.

According to the requirements of 1992 communiqué, financial statements prepared in Turkey must include a balance sheet, an income statement, a statement of cost of goods sold, a funds flow statement, a cashflow statement, a profit distribution statement and a statement of owners' equity, and notes to these statements. The balance sheet, income statement and notes to these statements constitute the fundamental statements, and the others are supplementary statements. A recent Ministry of Finance communiqué (September 1994), states that companies whose total assets are less than 25 billion Turkish lira and whose sales revenues are less than 50 billion Turkish lira are required to submit the fundamental statements only. Tax rules, on the other hand, require a balance sheet and an income statement from all first-class merchants. Financial statements have to be prepared within the three months following the end of an accounting period which is usually the year end.

In the appendix a condensed form balance sheet, an income statement and a cashflow statement are presented.

Turkish Procedural Tax Law requires that accounting and the related records must be kept for tax and taxable income determination. The Law also promulgates the acceptable documents and verification of these documents. The type of books a company should keep are determined by the company's size and whether it is a manufacturing, retail or service enterprise.

According to the tax rules, first-class merchants (annual purchases of more than TL720,000,000 or annual sales of TL864,000,000) should keep their books on what is called a 'balance sheet' basis (double-entry system). Such businesses are required to keep a journal, a general ledger, an inventory and balance sheet book, and a daily cash register (cash ledger). Secondclass merchants are merchants that pay corporate tax but are excluded from the double-entry requirement by a government permit. They are required to maintain a trading account register (working book) and a daily retail sales and proceeds register. In addition to these, manufacturing businesses should keep a manufacturing ledger. All firms can keep their books on the balance sheet basis if they want, even if they are not classified as first-class merchants. All accounting books kept must be certified by a notary (a brokerage controller agency certifies the books of brokerage firm).

Accounting records must be retained for five years after the accounting period according to the Procedural Tax Law and ten years according to the Commercial Code. During the five-year period records should be open to inspection at all times.

The Code of Obligations and the Commercial Code regulate the formation and activities of the businesses. The Code of Obligations controls 
ordinary partnerships which lack the status of legal entity. The Commercial Code, on the other hand, specifies the following types of legal entities:

1 general and special partnerships;

2 limited partnerships;

3 partnerships limited by shares;

4 corporations; and

5 cooperative societies.

There is no set of specific rules governing the accounting system of the type of companies. Ordinary, general and special partnerships, limited partnerships and cooperative societies can keep their books on the double-entry system or the working book system. Corporations and partnerships limited by shares are required to keep their books on the double-entry system.

\section{DISCUSSION OF TURKISH ACCOUNTING STANDARDS}

The accounting principles and policies stated in the 1992 communiqué and the $\mathrm{CMB}$ regulations follow the internationally accepted accounting principles and policies. These include underlying assumptions such as going concern, consistency, time period, unit of measure, and the basic principles such as cost, matching, prudence, objectivity, substance over form, materiality and full disclosure.

According to tax rules, on the other hand, in principle accrual accounting is recognized, but the treatment of certain items is closer to cash accounting. Although prudence is recognized, there is no specific disclosure requirement.

In the following paragraphs some items that are accounted for in a different way from that set out in international accounting standards will be discussed, and compared with the existing tax rules in Turkey. ${ }^{2}$ Major variations are summarized in Table 1.

\section{Fixed assets}

According to the accounting rules the cost of fixed assets includes items such as:

1 interest expense on self-constructed assets (capitalized until the asset is in use); and

2 foreign exchange losses on the purchase price of the assets, and the debts incurred for such assets, and long-term investments (capitalized until the debt for the asset or investment is paid in full),

in addition to the acquisition cost. According to tax rules, however, companies may continue to capitalize the interest expense related to loans used to finance such assets after the asset is in use. 
Table 1 Summary of generally accepted principles

\begin{tabular}{|c|c|c|}
\hline & International accounting standards & Turkish accounting standards \\
\hline $\begin{array}{l}\text { Marketable securities } \\
\text { (current assets) }\end{array}$ & Lower of cost or market & At cost \\
\hline $\begin{array}{r}\text { Inventories: valuation } \\
\text { cost flow }\end{array}$ & $\begin{array}{l}\text { Lower of cost or net realizable value } \\
\text { LIFO, FIFO, average and base } \\
\text { stock formula }\end{array}$ & $\begin{array}{l}\text { Lower of cost or net realizable value } \\
\text { LIFO, FIFO, weighted and moving } \\
\text { average }\end{array}$ \\
\hline $\begin{array}{l}\text { Fixed assets:valuation } \\
\text { depreciation }\end{array}$ & $\begin{array}{l}\text { Historical cost revaluation permitted } \\
\text { when disclosed over useful life of } \\
\text { asset }\end{array}$ & $\begin{array}{l}\text { Revaluation allowed } \\
\text { Various methods; tax practice } \\
\text { accepted }\end{array}$ \\
\hline Research and development & $\begin{array}{l}\text { Expensed unless specified criteria } \\
\text { met }\end{array}$ & Agrees with IAS \\
\hline Leases & Operating and capital lease methods & $\begin{array}{l}\text { No specific requirement, accepts tax } \\
\text { practice }\end{array}$ \\
\hline Deferred taxes & Deferred tax required & No requirement for deferred tax \\
\hline Borrowing costs & $\begin{array}{l}\text { Free to choose to capitalize or } \\
\text { expense }\end{array}$ & Capitalize \\
\hline $\begin{array}{l}\text { Investments in securities } \\
\text { long-term } 0-20 \% \\
\qquad \begin{array}{l}20-50 \% \\
\text { Greater than } 50 \%\end{array}\end{array}$ & $\begin{array}{l}\text { Cost or revalued amount } \\
\text { Equity } \\
\text { Consolidation required }\end{array}$ & $\begin{array}{l}\text { Cost } \\
\text { Cost } \\
\text { Consolidation not required }\end{array}$ \\
\hline Corporate acquisitions & $\begin{array}{l}\text { Purchase method; except in rare } \\
\text { cases pooling of interest allowed }\end{array}$ & No specific requirement \\
\hline Amortization of goodwill & $\begin{array}{l}\text { Deferred and amortized over useful } \\
\text { life }\end{array}$ & Amortized over maximum 5 years \\
\hline Disclosure & Full disclosure & Full disclosure \\
\hline
\end{tabular}

\footnotetext{
'May defer 20 per cent of income tax if research and development costs meet the Ministry of Finance criteria
} 
According to the $\mathrm{CMB}$ regulations and the Ministry of Finance requirements and tax practice since 1983, if companies have been using fixed assets (except land) for more than one year, then they may revalue the fixed assets and the related accumulated depreciation annually, except for capitalized foreign exchange losses. The revaluation rate is based on an index published by the Ministry of Finance every December , and is approximately equal to the country's annual inflation rate.

The difference between the net revalued fixed assets of current period (revalued cost less revalued accumulated depreciation) and the previous period is accumulated under the owners' equity section of the balance sheet under the name of revaluation fund. This revaluation surplus is non-taxable unless distributed, and may be added to capital via issuance of bonus (free) shares.

Accounting regulations require that companies disclose movements in fixed assets, depreciation methods used, and the effect of a change in the depreciation method. However, tax rules do not require any such disclosures.

\section{Inventory accounting}

The cost of inventories held for resale include invoice price, transport costs, customs' tax and duties and other costs incurred in manufacturing or in acquisition of goods. In addition, capitalization of foreign exchange losses and interest on purchased or manufactured inventories is permitted as long as they are to hand.

According to accounting and tax rules, cost flow methods that can be used are FIFO (first in first out), (LIFO) last in first out, weighted average and moving average. However, the law states that if companies choose to use the LIFO method, then they should continue using the LIFO method for a minimum of five consecutive years. Specific identification methods can be used for items if there is a need to precisely identify the cost of an item. The same method should be used for similar types of inventories.

According to accounting rules inventories are valued at the lower of cost or net realizable value. Net realizable value is the expected selling price less all additional costs to completion and all selling expenses related to the product.

Net realizable value is used when this value is less than cost by 10 per cent or more, and when there is no objective and reasonable forecast that this value will increase in the foreseeable future. If inventory is valued at lower than cost, then provisions must be made. The valuation loss is reported among the general administrative expenses in the income statement, and as a deduction from the value of inventories in the balance sheet. 
Tax and accounting treatment are similar in most cases except for the following items:

1 Termination benefits are treated as part of production costs for tax purposes and general administrative expenses for accounting purposes.

2 Standard costs are not acceptable for tax purposes.

3 Special procedures and permits are required for inventory reduction provisions; furthermore, sales price is preferably determined by the price of similar assets, or the past two- or three-month average price of the same asset.

The Ministry of Finance's 1992 communiqué and the CMB rules require the disclosure of the accounting policy adopted for valuation of inventories for the previous and current period; and if there is a change in the method, the effect is also disclosed. In addition to inventory, reduction provisions and costing systems are also disclosed.

\section{Equity investments and consolidation practices}

Equity investments include investments held temporarily or for long-term purposes. Temporary investments, both stocks and debt instruments, are classified as marketable securities. According to accounting rules these are valued at cost, and commissions and similar costs incurred during acquisition are classified under other expenses and losses section of the income statement. Either the moving or weighted average can be used for valuation purposes. Tax rules, on the other hand, require that these should be valued at cost plus face value of any free shares received, which are credited to a revaluation fund account.

Accounting rules allow for provisions for losses on the marketable securities if the market value is less than cost by 10 per cent or more, and when there is no objective and reasonable forecast that the value will increase in the foreseeable future. According to accounting rules disclosure of provisions and related losses are required in the balance sheets and income statement; and if the market value of investments is more than the cost than this should be disclosed in notes to the balance sheet. However, tax rules do not allow for any provisions, and do not require any disclosure.

Long-term equity investment regulations were declared by the CMB in two communiqués in 1989 and 1992 (Sermaye Piyasasi Kurulu, 1989; Sermaye Piyasasi Kurulu, 1992). The regulations specify the classes of equity investments and the related accounting principles as follows:

1 Long-term investments: these include financial investments that have lost marketability, or securities that are kept because of legal requirements, or long-term equity investments which do have any significant influence on the invested companies' management. 
2 Associate companies: if a company has a minimum of 10 per cent of the voting rights in an invested company's management, then it is believed that the investing company has significant influence, and the long-term equity investment is classified under this category.

3 Subsidiaries: if a company has 50 per cent or more of the voting rights or can influence the management of the invested company at the same rate, then these long-term equity investments are classified under this category.

Accounting and tax rules governing the valuation and recording procedures of these long-term investments are the same as temporary investments. CMB described the procedures of consolidation in the 1992 communiqué, and stated that if the companies wanted to prepare consolidated statements they should follow them. However, neither accounting rules nor tax rules require consolidated statements or equity accounting.

\section{Inflation accounting}

Although Turkey has experienced high rates of inflation in the last two decades, inflation accounting has not been fully developed. Except for revaluation of fixed assets and allowance of last in first out method inventory valuation, there are no regulations that require inflation accounting.

\section{AUDITING}

Until recently tax rules and regulations governed accounting record keeping and financial statement preparation in Turkey. The main reasons are that the majority of the companies were family owned, and accounting had no influential professional body. As a consequence, audit requirements were initiated late and standards have only recently been developed (in the late 1980s and early 1990s) by the CMB.

In 1945 the Ministry of Finance established its own team of accounts experts to undertake examination of accounting records for taxation purposes. Before that time the work of a small number of accountants had been accepted by the Ministry. The Commercial Code of 1956 relies on courts rather than on the accounting profession to provide the necessary confidence in the financial statements. The Procedural Tax Code defines and describes the works of tax auditors; however it did not have a clause on the works of accounting auditors until the Law of Accountants was passed in 1989.

From the late 1940s until 1989, ministers and members of the profession tried to bring a Law of Accountants before the Parliament without success. Law No. 3968 of Independent Accountancy, Independent Accountant 
Financial Advisership and Sworn-in Financial Advisership was enacted in 1989. The main reasons for this delay can be stated as:

1 closely held family owned companies;

2 heavy state intervention in the economic development;

3 delay in establishment of capital markets; and

4 solving accounting related problems in courts by the expertise of lawyers rather than the expertise of auditors.

Law No. 3968 establishes accountancy as a profession, and accountants as professionals in Turkey, i.e. accountants can express professional judgement on the unresolved issues, and have joint responsibility with management for the fairness of the audited financial statements. Before the Law was passed, the accounting profession was generally regarded as a mechanical profession which was only responsible for record keeping, and did not have high status in the society. Three categories of accounting professionals are created by Law No. 3968:

1 Independent accountant (IA): a trainee accountant who has a bachelor's degree in a related subject, and has to undertake further training and examinations for a period of time up to six years.

2 Independent accountant financial adviser (IAFA): a practising accountant and auditor, but without the authority to give an audit opinion. To be an IAFA, individuals should have a minimum of bachelor's degree in the requisite subjects, minimum of two years' training with an IAFA or SFA, and pass the examination to become an IAFA. IAFA examinations are conducted by the Turkish Union of Chambers of IAFAs and SFAs (Union for short).

3 Sworn-in financial adviser (SFA): an auditor but not an accountant, in that $\mathrm{s} /$ he cannot keep accounting books and records, nor establish an accounting office, nor be a partner in an already established accounting office. The emphasis is solely on the auditing capability with the requirement that an SFA, when signing an audit report, must be satisfied that the financial statements and tax returns have been compiled by persons and institutions in accordance with Turkish generally accepted accounting principles and auditing standards. To qualify as an SFA, the individuals should have ten years' of service as an IAFA and pass the SFA examination, or must have served as government tax inspectors for three years or be a university professor in a related field. A licence will be issued by the Union on the evidence of possession of these qualifications to permit performance and oath taking as an SFA.

The CMB specifies the general guidelines for the formation of auditing firms, and the auditing standards in a communique which came out in 1988 (Sermaye Piyasasi Kurulu, 1988). In the communiqué the qualifications of 
auditors, ethical issues and audit programme matters such as client acceptance, the evaluation criteria for internal control, evidence gathering, audit procedures and audit tests are specified. Furthermore, the standard audit report and departures from it are also discussed and examples are provided.

\section{CONCLUSION}

There has been a great expansion in international activity in the last three decades. For many companies this consists of trading activities; however on a larger scale, this expansion reflects investment in foreign firms or establishing foreign subsidiaries. Consequently, there has been an increasing demand for information on international accounting.

Although Turkey is a developing country in the Middle East with an increasing number of foreign investments and an emerging stock market, its accounting and auditing systems have not yet been studied. Turkish accounting practices have evolved considerably since the establishment of the Republic. However, the main changes have been initiated by the government, i.e. the Ministry of Finance, or government-controlled institutions, i.e. the CMB.

Turkish accountants themselves should establish control over the initiation and application of accounting principles and auditing standards, and should take the necessary steps to make their accounting principles and standards internationally comparable. Currently there is a promising move in that direction. In February 1994 an Accounting and Auditing Committee was formed with the mission of developing accounting and auditing standards. This committee is composed the representatives from following institutions and/or groups: universities, government auditors, the Treasury, the prime minister's Audit Board, the CMB, the Ministry of Finance and the Union. The committee has not yet published any standards.

Turkish accountants should recognize the need for more thorough professional training to reflect the social role and responsibility placed on them. Accountants themselves must also be self-disciplined and must endeavour to earn public confidence in the profession.

\section{APPENDIX: SUMMARY FORM MODEL BALANCE SHEET, INCOME STATEMENT AND CASHFLOW STATEMENT}

\section{Balance sheet}

Active (assets)

I Current assets

A Ready Assets

B Marketable securities

1 Allowance for valuation loss on securities (-) 
C Receivables from trade

1 Discount on notes receivable (-)

2 Allowance for doubtful accounts (-)

D Other receivables

1 Discount on notes receivable (-)

2 Allowance for doubtful accounts (-)

E Inventories

1 Allowance for valuation loss on inventories (-)

2 Advance payments for purchase orders

$F$ Prepaid expenses and accrued revenues

G Other current assets

Total current assets

II Long-term assets

A Trade receivables

1 Discount on notes receivable (-)

2 Allowance for doubtful accounts (-)

B Other receivables

1 Discount on notes receivable (-)

2 Allowance for doubtful accounts (-)

C Financial assets

1 Long-term equity investments

2 Loss in market value of (1) above (-)

3 Investments in Associate Companies

4 Subscribed capital payable to (3) above (-)

5 Loss in market value of (3) above (-)

6 Subsidiaries

7 Subscribed capital payable to (6) above (-)

8 Loss in market value of capital shares of subsidiaries (-)

9 Other financial assets

10 Loss in market value of (9) (-)

D Tangible assets

1 Property, plant and equipment (gross)

2 Accumulated depreciation (-)

3 On - going investments

4 Advance payments

E Intangible assets

1 Intangibles (gross)

2 Accumulated amortization (-)

3 Advance payments

F Special wasting assets

1 Special wasting assets

2 Accumulated depletion (-)

3 Advance payments

$G$ Prepaid expenses and accrued revenues 
$\mathrm{H}$ Other long-term assets

Total long-term assets

Total active (assets)

\section{Passive (sources)}

I Current liabilities
A Short term credits
B Trade debts
1 Discount on notes payable (-)
C Other debts
1 Discount on notes payable (-)
D Advances payments received
E Taxes and other duties payable
F Provisions for debt and expenses
1 Period income tax provision
2 Prepaid income tax (-)
3 Pension provisions
4 Other debt and expense provisions
$G$ Revenues received in advance and accrued expenses
H Other current liabilities
Total current liabilities

II Long-term liabilities

A Loans and credits

B Trade debts

1 Discount on notes payable $(-)$.

C Other debts

1 Discount on notes payable (-)

D Advances payments received

E Provisions for debt and expenses

1 Pension provisions

2 Other debt and expense provisions

$F$ Revenues received in advance and accrued expenses

$\mathrm{H}$ Other long-term liabilities

Total long-term liabilities

IIl Owners' equity

A Paid in capital

1 Capital subscribed

2 Unpaid capital (-)

B Capital reserves

1 Additional paid - in capital

2 Gain on cancellation of stocks

3 Revaluation fund of fixed assets 


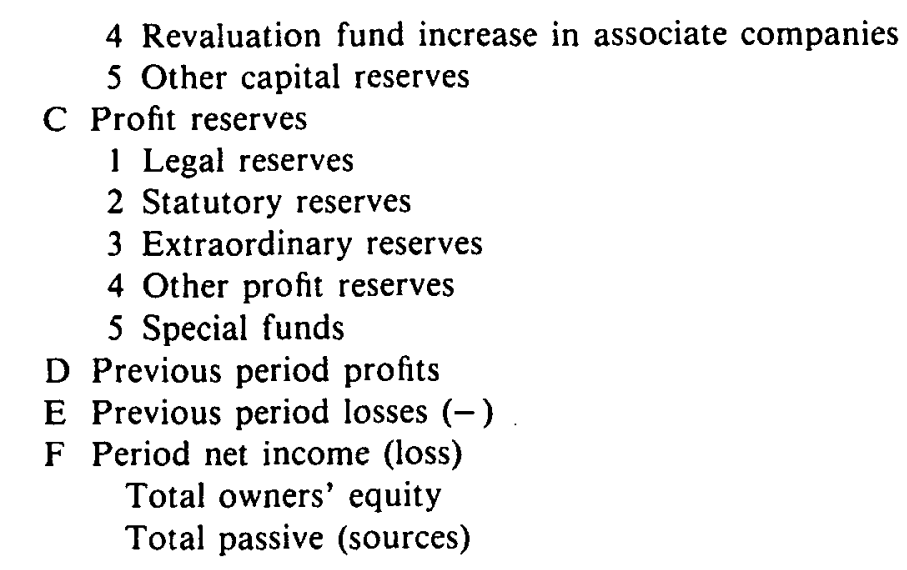

\section{Notes to balance sheets}

Notes include information such as:

1 authorization limit of capital when appropriate;

2 payments to top managers;

3 insurance value of the assets;

4 guarantees and mortgages secured for receivables;

5 guarantees and mortgages given for loans ;

6 amount of commitments not disclosed among the liabilities;

7 foreign currency on hand and at the banks (list by currency);

8 receivables from foreign countries (list by currency);

9 debt to foreign countries-including advance payments (list by currency);

10 secured bonds and financing bonds;

11 amount of investment incentives to be used in the coming years;

12 amount of convertible bonds;

13 type and amount of share capital;

14 amount of issued stock in the current period;

15 name of the owner or name and share of owners' who have 10 per cent or more of the capital;

16 name, share percentage, and total capital of long-term equity investments where there is significant influence and more than 50 per cent ownership;

17 inventory valuation method (a) in the current period; (b) in the previous period; (c) if there is change in the valuation method; effect of change;

18 property,plant, and equipment movement in the current period;

19 trade receivables or payables to parent company or subsidiaries, and long-term equity investments with significant influence;

20 average number of personnel in the current period; 
21 disclosure of the events after the balance sheet date;

22 disclosure of contingent losses and gains;

23 nature of changes in the accounting policies, and their effect on income;

24 disclosure of compensating balances;

25 disclosure of the invested companies who had issued securities and the amount;

26 disclosure of the amount of bonus shares because of capital increase through internal fund transfers;

27 total interest debt on all outstanding loans until maturity date;

28 total of guarantees, etc. given on behalf of the invested companies;

29 disclosure of other issues that affect the financial statements;

30 approval date of balance sheet.

\section{Income statement}

A Sales revenue

B Sales returns and allowances

C Net sales

D Cost of sales (-)

Gross margin (gross sales profit or loss)

E Operating expenses (-)

Operating income (loss)

$F$ Non-operating revenue and gains

$G$ Non-operating expenses and losses (-)

$H$ Financing expenses (-)

Income before extraordinary items

I Extraordinary revenue and gains

J Extraordinary expenses and losses Income before tax

$\mathrm{K}$ Provision for income taxes and other legal obligations Net income (Loss)

\section{Net income (loss)}

1 total depreciation, amortization, and depletion expenses of the period;

2 total expenses for the allowances;

3 total financing expenses; allocated to production costs, to property, plant and equipment costs, and expensed directly;

4 amount of interest paid to parent company or subsidiaries, and invested companies (when the amount exceeds 20 per cent of the total it will shown separately);

5 sales to parent company or subsidiaries, and invested companies (when the amount exceeds 20 per cent of the total it will shown separately); 
6 rent, interest received and paid to parent company or subsidiaries and invested companies (when the amount exceeds 20 per cent of the total it will shown separately);

7 salaries and fringe benefits provided to the top management, including the board of directors, president and general director;

8 depreciation method used; and effect of changes in the methods on income;

9 costing system (e.g. process or job order) and cost flow methods (e.g. last in first out; average; first in first out);

10 if applicable, the reason for not having full or partial inventory count;

11 total revenue from by products (domestic and international), and service revenue (when the amount exceeds 20 per cent of the total it will shown separately);

12 previous period revenue and expense amounts, and the amount and reason of losses and expenses;

13 earnings per share calculated separately for common stock and preferred stock;

\section{Cashflow statement}

A Cash balance beginning of the period

B Cash collections during the period

1 Cash collected from sales

a Net sales

b Decreases in trade receivables

c Increases in trade receivables (-)

2 Cash received from other operations

3 Cash received from extraordinary revenues and gains

4 Cash received from increases in short-term loans and credits

a From security issuance

b Credit taken

c Other increases

5 Cash received from increases in long-term loans and credits

a From security issuance

b Credit taken

c Other increases

6 Cash received from increases in capital

7 Cash received from additional paid-in capital

8 Other cash collections

C Cash disbursements during the period

1 Cash disbursements for costs

a Cost of sales

b Increases in inventories

c Decreases in trade payables 
d Increases in trade payables (-)

e Depreciation and other non-cash expenses (-)

$f$ Decreases in inventories (-)

2 Cash disbursements for operations

a Research and development expenses

b Selling and advertising expenses

3 Cash disbursements for other expenses and losses

a Other expenses and losses

b Other depreciation or non-cash expenses

4 Cash disbursements for financing expenses

5 Cash disbursements for extraordinary expenses and losses

a Extraordinary expenses and losses

b Other depreciation or non-cash expenses

6 Cash disbursements for property, plant and equipment

7 Cash disbursements for short-term loans credits
a Securities principal payments
b Principal payment of loans
c Other payments

8 Cash disbursements for long-term loans credits

a Securities principal payments

b Principal payment of loans

c Other payments

9 Taxes and duties paid

10 Dividends paid

11 Other disbursements

$D$ Cash balance end of the period $(A+B+C)$

$E$ Decrease or increase in cash $(B-C)$

\section{NOTES}

1 At the end of 1990 , the number of foreign firms in the county was 1813 with a capital stock of 4 trillion Turkish lira (approximately 1.2 billion US\$); from Main Economic Indicators 1991, State Planning Organization.

2 A detailed description of the Turkish accounting system and tax rules will be found in Simga-Mugan (1994).

\section{REFERENCES}

Agarwal, N. K. and Joshi, P. L. (1991) 'Small business corporations in Turkey: accountants' attitudes towards accounting principles', The Chartered Accountant, 10-12.

Bilginoglu, Fahir (1988) Muhasebe Organizasyonu (Accounting Organization). Istanbul Universitesi Muhasebe Enstitusu Yayin No. 54, Istanbul.

Bursal, Nasuhi, I. (1984) 'The accounting environment and some recent developments in Turkey', The International Journal of Accounting, 93-127. Volume 19. 
Ceyhun, Fikret (1992) 'Turkey's debt crises in historical perspectives: a critical analysis', METU Studies in Development, 19, 9-49.

Goktan, Erkut (1968) The Present and Potential Role of Accounting in the Economic Development of Turkey. PhD dissertation, University of North Carolina.

Kilicbay, Ahmet (1991) Turk Ekonomisi (Turkish Economy). Ankara: Turkiye Is Bankasi Kultur Yayinlari No. 263.

Maliye ve Gumruk Bakanligi (1992) Muhasebe Sistemi Uygulama Genel Tebligi, Resmi Gazete (Ministry of Finance and Customs, General Regulations Controlling the Application of the Accounting System, Official Gazette), 26 December.

Ogan, Pekin (1978) 'Turkish accountancy: an assessment of its effectiveness and recommendations for improvements', The International Journal of Accounting, 133-47. Volume 13.

Sermaye Piyasasi Kurulu (1988) Bagimsiz Denetleme Kuruluslari ve Denetcilere Iliskin Genel Esaslar, Seri X, No. 3, Resmi Gazete (General Regulations related to the Independent Auditing Firms, and Auditors, Capital Markets Board, Official Gazette), 18 June.

Sermaye Piyasasi Kurulu (1989) Sermaye Piyasasinda Mali Tablo ve Raporlara iliskin ilke ve Kurallar Hakkinda Teblig, Seri XI, No. 1, Resmi Gazete 29 January (Capital Markets Board (1989), Rules for Accounting Standards Governing Financial Statements, Series XI, No.1, Official Gazette, 29 January).

Sermaye Piyasasi Kurulu (1992) Sermaye Piyasasinda Konsolide Mali Tablolara Iliskin Ilke ve Kurallar Hakkinda Teblig Seri X1, No. 7, Resmi Gazete (Rules for Consolidated Financial Statements, Capital Markets Board, Official Gazette) 28 March.

Tumer, Erol (1972) An Investigation of the Present and Potential Role of Financial Accounting in the Capital Market in Turkey. PhD Dissertation, University of Illinois at Urbana-Champaign.

Turkiye'de Ekonomik Yapi Degismeleri 1923-1988 (1989) Turkiye Ticaret, Sanayi, Deniz odalari ve Ticaret Borsalari Birligi.

Turkiyede Toplumsal ve Ekonomik Gelismenin 50 yili (1973) Devlet Istatistik Enstitusu (State Statistics Institute), 152.

Var, Turgut (1976) 'The current accounting education and practice in Turkey', International Accountant, 4, 8-12.

Walstedt, Bertil (1980) State Economic Enterprises in a Mixed Economy, the Turkish Case, World Bank, Baltimore, MD, 61-73. 